\title{
Bromocriptine-induced implantation during lactation in the rat
}

\author{
A. P. F. Flint and Marilyn B. Renfree* \\ A.R.C. Institute of Animal Physiology, Babraham, Cambridge CB2 4AT, U.K. and \\ *School of Environmental and Life Sciences, Murdoch University, Western Australia 6150
}

\begin{abstract}
Summary. When lactating rats were mated at the post-partum oestrus, treated with a single dose of bromocriptine ( $2 \mathrm{mg} / \mathrm{kg}$ body wt) 7 days later, and killed on Day 11 , implantation was induced in $8 / 24$ animals. When the litter was removed at the time of bromocriptine treatment $5 / 9$ rats had implantations compared with $9 / 10$ after litter removal alone.
\end{abstract}

\section{Introduction}

Implantation in rats requires the presence of oestrogens, which are secreted by the ovaries on Day 4 of pregnancy in response to a brief gonadotrophin surge (see Psychoyos, 1973). If lactating rats are mated immediately post partum, implantation is delayed by up to 11 days, depending on the number of young suckled (see Amoroso \& Finn, 1962), presumably due to an oestrogen deficiency resulting from a relative lack of gonadotrophin secretion (Hammons, Velasco \& Rothchild, 1973; Raud, 1974). Suckling inhibits gonadotrophin secretion (Ford \& Melampy, 1973), possibly through the release of prolactin (Raud, 1974; Muralidhar, Maneckjee \& Moudgal, 1977). Hyperprolactinaemia, resulting from suckling, administration of prolactin or release by a transplanted pituitary gland, is associated with low serum gonadotrophin levels and inhibition of gonadotrophin release in response to administered LH-RH (Lu, Chan, Grandison, Huang \& Meites, 1976; Muralidhar et al., 1977; McNeilly, Sharpe, Davidson \& Fraser, 1978).

If hyperprolactinaemia is important in the inhibition of ovarian oestrogen secretion during lactational embryonic diapause, reducing prolactin levels should lead to implantation and this was tested in the present study.

\section{Materials and Methods}

In Exp. 1 at Babraham 28 Wistar rats were used in July and August 1978. In Exp. 2 at Murdoch in May 1979 the 35 Irish hooded rats used were of the PVG/C 1638 strain bred locally. Animals were kept in similar photoperiod and temperature-controlled environments $\left(21-25^{\circ} \mathrm{C}\right.$; lights on 07:00-19:00 h). In Exp. 1 the animals were of varied parity, but those in Exp. 2 were all primiparous.

Pregnant females were paired with intact males $2-3$ days before parturition and post-partum mating (Day 1) was confirmed by spermatozoa in the vaginal smears taken 09:00-10:00 h each day. Litter size was adjusted within $24 \mathrm{~h}$ of birth to $10-12$ in Exp. 1 and 10 in Exp. 2. The treatments in the two experiments were as follows: Group 1, no treatment; Group 2, young removed on Day 8 post coitum (p.c.); Group 3 rats received an intraperitoneal injection of bromocriptine (2-bromo- $\alpha$-ergocryptine methane sulphonate: Sandoz) at a dose of $2 \mathrm{mg} / \mathrm{kg}$ body 
weight, dissolved in saline $(9 \mathrm{~g} \mathrm{NaCl} / 1)$ containing $20 \% \mathrm{v} / \mathrm{v}$ ethanol, on Day 8 p.c.; in Group 4 bromocriptine was given as in Group 3 but the young were removed simultaneously. All animals were killed on Day 11 p.c. Pontamine Sky Blue 6BX (G. T. Gurr Ltd, London; $1 \mathrm{ml}$ of a 10\% $\mathrm{w} / \mathrm{v}$ solution in saline) was administered by intracardiac injection under light ether anaesthesia 20 min before death and the uterus was examined for implantation (dye) sites. Uteri without dye sites were flushed with saline and flushings were examined for the presence of blastocysts. Rats with neither dye sites nor flushed blastocysts were designated non-pregnant.

\section{Results}

Bromocriptine caused premature implantation in approximately $30 \%$ of the rats treated (Table 1). Of the 10 pregnant rats in Group 3 of Exp. 1, 4 were suckling more than 10 young and did not show implantation sites. Implantation sites were seen in 4 of the other 6 females which were suckling only 10 young each. Pregnancy loss in bromocriptine-treated animals was high in both experiments, but in Exp. 2 there was a comparable rate of loss in the control groups (Groups 1 and 2).

Table 1. Effect of bromocriptine administered on Day 8 of suckling-induced delayed implantation in rats killed on Day 11

\begin{tabular}{|c|c|c|c|c|c|c|c|c|c|}
\hline \multirow[b]{2}{*}{ Group } & \multirow[b]{2}{*}{ Treatment } & \multicolumn{4}{|c|}{ Experiment 1 (Babraham) } & \multicolumn{4}{|c|}{ Experiment 2 (Murdoch) } \\
\hline & & $\begin{array}{l}\text { No. } \\
\text { of } \\
\text { rats }\end{array}$ & $\begin{array}{l}\text { No. } \\
\text { in } \\
\text { delay }\end{array}$ & $\begin{array}{l}\text { No. with } \\
\text { implan- } \\
\text { tations }\end{array}$ & $\begin{array}{c}\text { No. not } \\
\text { pregnant }\end{array}$ & $\begin{array}{l}\text { No. } \\
\text { of } \\
\text { rats }\end{array}$ & $\begin{array}{l}\text { No. } \\
\text { in } \\
\text { delay }\end{array}$ & $\begin{array}{l}\text { No. with } \\
\text { implan- } \\
\text { tations }\end{array}$ & $\begin{array}{c}\text { No. not } \\
\text { pregnant }\end{array}$ \\
\hline 1 & No treatment & 7 & 7 & 0 & 0 & 13 & 9 & 1 & 3 \\
\hline 2 & Litter removal & 4 & 0 & 4 & 0 & 6 & 0 & 5 & 1 \\
\hline 3 & Bromocriptine* & 13 & 6 & 4 & 3 & 11 & 6 & 4 & 1 \\
\hline 4 & $\begin{array}{l}\text { Bromocriptine }+ \text { litter } \\
\text { removal }\end{array}$ & 4 & 0 & 2 & 2 & 5 & 0 & 3 & 2 \\
\hline
\end{tabular}

* For effect of bromocriptine on implantation, $P=0.023$ (Fisher exact probability test).

\section{Discussion}

The results demonstrate that implantation can be induced in suckling rats by bromocriptine, and therefore support the hypothesis that a lactation-induced prolactinaemia is responsible for the failure of gonadotrophin secretion that normally results in lactational delay. They do not, however, prove that the inhibitory effect of suckling on gonadotrophin secretion involves prolactin release; if bromocriptine treatment had resulted in a transient decline in sucking by the young, this in itself may have allowed a rise in gonadotrophin levels, and thus implantation as suggested by Lu et al. (1978).

The finding that pregnancy loss was relatively low after administration of bromocriptine at 2 $\mathrm{mg} / \mathrm{kg}$ is difficult to reconcile with the observation that bromocriptine blocks pseudopregnancy and causes abortion at lower doses than those used here (at an $\mathrm{ED}_{50}$ of approximately 0.7 $\mathrm{mg} / \mathrm{kg}$ in both cases; Fluckiger, 1972). One possible explanation is that lactating rats are less sensitive to bromocriptine than those which are not lactating, because Fluckiger (1972) showed the $\mathrm{ED}_{50}$ for inhibition of weight gain in sucking young to be above $3 \mathrm{mg} / \mathrm{kg}$. It seems likely, therefore, that although higher doses of bromocriptine might have increased the proportions of rats implanting, they might also have increased pregnancy loss; a high rate of pregnancy loss was reported by Ford \& Yoshinaga (1975) in lactating pregnant rats given ergocryptine on Day 9 of pregnancy. 
A single intramuscular injection of bromocriptine also results in reactivation of the blastocyst in the tammar wallaby, in which prolactin exerts a tonic inhibition on the corpus luteum; removal of prolactin by hypophysectomy or administration of progesterone causes blastocyst reactivation (see Tyndale-Biscoe, 1979). The mechanisms controlling embryonic diapause and embryo reactivation differ in the rat and the tammar therefore, although they both depend on prolactin; in rats hypophysectomy blocks implantation (Psychoyos, 1973), prolactin stimulates progesterone secretion by the corpus luteum during diapause (Ford \& Yoshinaga, 1975 ) and implantation is not induced by progesterone administration (Canivenc \& Laffargue, 1956). In addition there is presumably a difference in uterine response to progesterone. The existence of two distinct mechanisms suggests that these species have responded in different ways to evolutionary pressures leading to the adoption of lactation-induced prolactin secretion as a method of causing embryonic diapause, but we are unable to continue with these studies.

We thank Helen Shaw and Donna Bicknell for assistance, Mr D. E. Walters for advice on statistical treatment of the results and Dr R. B. Heap, Dr D. W. Lincoln and Dr A. McLaren for helpful criticism of the manuscript.

\section{References}

Amoroso, E.C. \& Finn, C.A. (1962) Ovarian activity during gestation, ovum transport and implantation. In The Ovary, lst edn, Vol. 1, pp. 451-537. Ed. S. Zuckerman. Academic Press, New York.

Canivenc, R. \& Laffargue, M. (1956) Survie prolongée d'oeufs fécondés non implantés, dans l'uterus de rattes castrées et injectées de progesterone. $C . r$. hebd. Séanc. Acad. Sci. Paris D 242, 2857-2860.

Fluckiger, E. (1972) Drugs and the control of prolactin secretion. In Prolactin and Carcinogenesis, pp. 162-171. Eds A. R. Boyns \& K. Griffiths. AlphaOmega-Alpha, Cardiff.

Ford, J.J. \& Melampy, R.M. (1973) Gonadotrophin levels in lactating rats: effects of ovariectomy. Endocrinology 93, 540-547.

Ford, J.J. \& Yoshinaga, K. (1975) The role of prolactin in the luteotrophic process of lactating rats. Endocrinology 96, 335-339.

Hammons, J.-A., Velasco, M. \& Rothchild, I. (1973) Effect of the sudden withdrawal or increase of suckling on serum $\mathrm{LH}$ levels in ovariectomized post-parturient rats. Endocrinology 92, 206-211.

Lu, K.H., Chan, H.T., Grandison, L., Huang, H.H. \& Meites, J. (1976) Reduced luteinizing hormone release by synthetic luteinizing hormone-releasing hormone (LHRH) in post-partum lactating rats. Endocrinology 98, 1235-1240.

Lu, K.H., Chan, H.T., Huang, H.H., Grandison, L., Marshall, S. \& Meites, J. (1978) Relation between prolactin and gonadotrophin secretion in postpartum lactating rats. J. Endocr. 68, 241-250.

MeNeilly, A.S., Sharpe, R.M., Davidson, D.W. \& Fraser, H.M. (1978) Inhibition of gonadotrophin secretion by induced hyperprolactinaemia in the male rat. J. Endocr. 79, 59-68.

Muralidhar, K., Maneckjee, R. \& Moudgal, N.R. (1977) Inhibition of in vivo pituitary release of luteinizing hormone in lactating rats by exogenous prolactin. Endocrinology 100, 1137-1142.

Psychoyos, A. (1973) Hormonal control of ovoimplantation. Vitams Horm. 31, 201-256.

Raud, J.R. (1974) The regulation of ovum implantation in the rat by endogenous and exogenous FSH and prolactin: possible role of ovarian follicles. Biol. Reprod. 10, 327-334.

Tyndale-Biscoe, C.H. (1979) Hormonal control of embryonic diapause and reactivation in the tammar wallaby. In Maternal Recognition of Pregnancy (Ciba Fdn Symp. No. 64), pp. 173-185. Ed. J. Whelan. Excerpta Medica, Amsterdam. 